Conservation and Society 17(1): 120-121, 2019

Megan Ybarra. Green Wars: Colonization and Conservation in the Maya Forest. Oakland, CA: University of California Press. 2018. ix-xii + 204 pages. Hardcover. ISBN: 9780520295162. USD 85.00; GBP 71.00.

Green Wars:

\section{Colonization and Conservation in the Maya Forest}

Global conservation efforts have come under increased academic and activist scrutiny in recent years. The nature protection agendas formulated by big international conservation organisations at conflictive forest frontiers in the global South - and their ambiguous links to neoliberal agendas of payment for environmental services and market-based ecotourism - have figured prominently in academic and public discussion. Conservation through enclosure and green grabbing by primitive accumulation in different parts of Latin America has also been widely investigated in recent political-ecological and critical conservation studies. Megan Ybarra's book, Green Wars: Colonization and Conservation in the Maya Forest, focuses on international conservation efforts to protect the 1.6 million ha Maya Forest in northern Guatemala as a hotspot of global biodiversity. Through her careful ethnographic analysis, she contributes significantly to contemporary debates, convincingly showing that global conservation efforts have turned lowland Maya Indians into immigrants on their own land.

Green Wars offers a sophisticated discussion of complicated links between conservation politics, authoritarian state-making, settler colonialism, and racialised dispossession of indigenous peoples in tropical forest-frontiers. Ybarra meticulously demonstrates the political-economic processes that have led to large-scale land transactions and sedimented trajectories of resource accumulation by dispossession in Guatemala. Moreover, drawing on feminist political ecology, postcolonial perspectives, and critical race theories, Ybarra addresses a crucial lacuna in conventional studies of conflicts over conservation that focus solely on struggles over material resources. The analysis carefully shows how seemingly benevolent conservation projects become framed by a settler logic of elimination of the Other and thus end up justifying violent displacement of Indians from their territories. Although international conservation organisations have not called for violent dispossessions, by framing their agendas with imaginaries of the Maya forest as pristine wilderness and Q'eqchi' Indians as unruly reserve invaders, they ultimately support racialised resource-access exclusion. By defining indigenous land-tenure struggles outside their conservation mandate, global conservation organisations fail to combine efforts for sustainable conservation and sustainable livelihoods in indigenous territories.

In her ethnographic research, carried out in politically volatile circumstances, Ybarra laudably reflects her role as a gringo researcher, showing solidarity with indigenous struggles for justice and decolonisation of the racialised settler system, while at the same time negotiating with advocates of land-extensive conservation programmes. Using sophisticated archival analysis and life-history interviews, Ibarra tracks the decades-long forms of physical and symbolic violence with which state authorities, land-owning elite, and military forces have sought to dispossess Maya Indians of their territory. Recent efforts to enclose the Maya Forest for conservation violate indigenous rights to resource access, while provoking a series of injustices including state-led land dispossessions, structural state violence in the form of unavailability of basic services, and state-sanctioned private violence against non-consensual communities. Through a careful analysis of historical maps and land-registration archives, Ybarra shows that many of the lands inside the Maya Biosphere Reserve, although framed as core conservation areas with no human occupants by the park officials, consist of indigenous working lands, sacred landscapes, and places of territoriality.

Green Wars also provides an interesting analysis of how indigenous contestations against fortress conservation are not just battles over resource access and land ownership but also struggles over cultural identity and symbolic meanings in which different knowledges, ideologies, and ontologies of nature clash with each other. Ybarra shows how the collective memory of repeated state violence, accumulation by dispossession, and denial of indigenous ontologies frames Maya interpretations of contemporary conservation agendas, while the indigenous cartography of refusal rejects proposals for subsuming Q'eqchi' territoriality under the settler logics of land ownership. Instead of portraying Maya Indians as passive victims of structural state violence, Ibarra demonstrates the indigenous stamina for land activism and alternative visions of territoriality. As Ybarra thought-provokingly asserts, Q'eqchi' show an interruptive capacity to live within and beyond settler society by redirecting their imagination to other questions, other ideas, and other ways of knowing.

Based on the lively debate over the political ontology of nature in current political-ecological and post-colonial approaches, it would have been interesting to know even more about ontological questions related to struggles over nature protection and local livelihoods in Guatemala. Given that Ybarra carried out long-term ethnographic field research in the area, it would have been enlightening if she had analysed the Q'eqchi' views of the political ontology of nature in greater depth. Deserving of more attention are her inspiring arguments that, in Q'eqchi' struggles for recuperation, ontologies of 
territory as identity and a spiritual relationship with the landscape are intimately interwoven with an indigenous way of farming and the daily search for livelihoods.

Based on the facts that this monograph is entitled Green Wars and that Ybarra considers a feminist political ecology to offer a good way to analyse the power relations in nature conservation, providing more detailed analyses of the views of conservation experts and development practitioners of the struggles over conservation and indigenous livelihoods would have made her analysis more convincing. More discussion of how the conservation authorities perceived the environmental-social transformations within the biosphere reserve and its surroundings, and how they explained the causes and consequences of such transformations could have deepened analysis. While supporting epistemological pluralism, Ybarra's postcolonial analysis of Indians as Other is, in parts, based on an unintentionally dichotomic view of ladinos versus indigenous people. More careful examination of the multifaceted relationship between the Indians and landpoor ladino populations in the struggles for justice in Petén and Alta Verapaz might have prevented this.

Chapters One, Two, and Four are theoretically coherent and ethnographically rich analyses, with a careful focus on the links between conservation efforts, settler colonialism, and state violence. Chapter One provides a detailed analysis of the histories of state violence that politicised Maya forests and criminalised lowland Q'eqchi' territorial rights. Chapter Two examines the conservationists' supposedly apolitical projects for nature protection and their representations of lowland Maya as unruly migrants, while Chapter Four offers a rich case study of settler colonialism overlaid by a questionable veneer of conservation. In contrast, Chapter Three, although analysing interesting questions of racialised ladino ideologies, suffers from clear links to conservation. Furthermore, while Chapters One and Two carefully show how advocacy of fortress conservation by conservation organisations is a reason why local civil-war survivors associate international conservation efforts with violence, analysis in Chapter Five lacks the same sort of thoroughness. This chapter, focusing on links between narco-terrorism and conservation ideologies, contains repetition and lacks sufficient empirical grounds for claiming that the "effect of twenty-first century green wars has been to subject indigenous territorial claims to narconarratives, interpellating all communities that contest the legitimacy of protected areas to putative narcos" (p. 152). Overall, the different chapters of the book could have been woven together more coherently, although this weakness in organising structure might be the result of the material from several chapters having already been published in articles in scientific journals. The book's maps are highly illustrative; however, the quality of the few photos included could have received more attention.
The concluding chapter emphasises the Maya Indians' call for decolonisation by recognising the intimate relationship between indigenous peoples and the land. As the monograph presents thought-provoking, highly relevant theoretical and policy-oriented debates on conservation and livelihoods, the conclusion could have provided a more analytical synthesis of the main theoretical insights and societally relevant findings of the study. In its present form, the conclusion comprises a fairly normative list of "musts" that morally aware Northern scholars and justice advocates should take into account. Instead of such lists, it could have focused more on indigenous imaginings for decolonial futures.

Ultimately, Green Wars is a very welcome contribution to the existing literature on complex relations between global conservation efforts, struggles for local livelihoods and recognition of indigenous territorial rights. It interestingly shows how indigenous people engage with an ambiguous both/ and politics when coping within settler legal systems, while going beyond settler-state subjections. It also demonstrates how indigenous calls for justice demand a collective rethinking of environmental-social relations as the locus where nature and society co-produce each other, and that land, forest, water, air, and subsoil constitute a lived landscape that cannot be commodified. In such an ontology, financial compensation is not an answer to indigenous claims for self-determination. I highly recommend this book for researchers and graduate students in geography, anthropology, political science, sociology, and environmental social science, as well as for conservation experts, environmental activists, social justice and human rights advocates, policy-makers, and development practitioners working on sustainability issues in different parts of the world.

Anja Nygren

Development of Studies, Faculty of Social Sciences, University of Helsinki, Finland E-mail:anja.nygren@helsinki.fi

Copyright: (C) Nygren 2018. This is an open access article distributed under the terms of the Creative Commons Attribution License, which permits unrestricted use and distribution of the article, provided the original work is cited. Published by Wolters Kluwer - Medknow, Mumbai | Managed by the Ashoka Trust for Research in Ecology and the Environment (ATREE), Bangalore. For reprints contact: reprints@medknow.com

\begin{tabular}{|l|l|}
\hline \multicolumn{2}{|c|}{ Access this article online } \\
\hline Quick Response Code: & Website: \\
\hline & www.conservationandsociety.org \\
\cline { 2 - 3 } & \\
\hline
\end{tabular}

